\title{
Model for building traction information of suburban rolling stock on hydrogen fuel
}

\author{
Anatoly Falendysh ${ }^{1}{ }^{*}$, Volodymyr Dzhus ${ }^{2}$, Olha Kletska ${ }^{1}$, Oleg Kosariev ${ }^{1}$, and Jan Dizo ${ }^{3}$ \\ ${ }^{1}$ Ukrainian state university of railway transport, Heat Engineering and Heat Engines, Kharkov, Ukraine \\ ${ }^{2}$ DNURT, Department Chair of rolling stock and railway, 79052 Lviv, I.Blazhkevych Str., 12-a, Ukraine \\ ${ }^{3}$ University of Zilina, Department of Transport and Handling Machines, Zilina, Slovakia
}

\begin{abstract}
The materials consider the possibility of using hydrogen as a fuel for suburban rolling stock in Ukraine. The analysis of the use of hydrogen fuel in transport in various countries of the world is carried out. One of the main stages of calculating the rolling stock is the construction of its traction characteristic, which largely depends on the type of power plant. Therefore, a model has been developed for constructing traction characteristics of a suburban rolling stock when it is converted to hydrogen fuel. For this purpose, an analysis of power equipment with an energy source from a polymer of an exchange membrane fuel cell and methods of connecting their batteries to blocks is done. The scheme of power transmission for the rolling stock is proposed and its efficiency coefficient is preliminarily calculated. The main technical indicators of suburban rolling stock in Ukraine at the moment and using proton-exchange membrane fuel cells on it are considered. Preliminary consideration is given to the operation parameters of the electric circuit of the rolling stock under various modes of its motion. The traction characteristic of a suburban mobile suction on hydrogen fuel is constructed. The proposed model is implemented in the software product MathLab.
\end{abstract}

\section{Introduction}

The greater part of all transportations in Ukraine is provided by railway transport [1]. But at the same time, more than $90 \%$ of it is currently behind the world technical progress. In Ukraine, scientific works and practical research are mainly aimed at developing activities related to the extension of the life of the already existing rolling stock. At the moment, the new rolling stock in the country is being produced by Kryukovsky Carriage Works. He developed and produced an electric train ECP1 (Tarpan) and a diesel train DPKr-1 [2].

In the world there is a tendency to increase the speed of rolling stock movement and use of different types of thrust without harmful emissions into the environment. Therefore, the issue of developing our own high-speed and environmentally friendly rolling stock for Ukraine is topical. This is confirmed by the strategy for the development of "Ukrzaliznytsya" PAT until 2021, dated 12.09.2017 [3].

\section{Research and discussion of the oresults}

The use of hydrogen as a fuel in transport power plants is possible in two ways:

- as a fuel for internal combustion engines [4,9];
- as a fuel cell, the principle of operation of which is based on electrolysis $[5,6,9]$.

Work on the use of hydrogen fuel in transport along both tracks has been carried out in many countries around the world since the nineteenth century [4-10]. The use of hydrogen in railway transport has begun to receive attention only in the last 20 years. Therefore, further studies are continued for the use of hydrogen in power railroad transport usa- novs.

Scientists from the Tokyo Railway Research Institute (Japan) and the French company Alstom went on the second route of using hydrogen as an energy plant. For example, Alstom presented a prototype of the Coradia iLint rail car designed and built on the basis of the Lint 54 at the World Rail Transport Exhibition [10-13].

Also, the issues of the use of hydrogen in rail transport are given great attention in the United States, Britain and China. VNIIZhT scientists propose the use of hydrogen on the rolling stock of Russian railways [14]. Variants of the use of hybrid power plants on the modernized rolling stock in Ukraine are considered in [15-19].

Thus, the second version of the use of hydrogen as a fuel (the use of proton-exchange membrane fuel cells in hybrid power transmission) for a motor-car rolling stock was considered in [20]. A model for the technical and economic evaluation of the rolling stock on hydrogen fuel is proposed, the necessary equipment and its location for the modernization of the diesel train are

Corresponding author: fap hiit@ukr.ne 
preliminarily determined. But the issues of traction calculations for rolling stock on hydrogen fuel are not considered.

Therefore, consideration of carrying out traction calculations for rolling stock using hydrogen fuel is currently an urgent and timely task.

Based on preliminary calculations [20], for further work on the modernization of the rolling stock by power plants using hydrogen fuel, the diesel train DPKr2 (Fig.1).

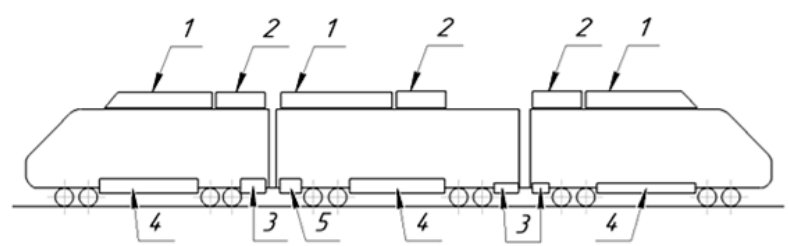

1 - Fuel tank, 2 - PEMFC, 3 - Invertor for traction motors, 4 - Li-Ion batteries, 5 - Invertor for indoor needs.

Fig.1. Location equipment on a multiple units rolling stock rolling stock with hydrogen fuel.

It is supposed to use the following equipment in advance: proton-exchange membrane fuel cells (PEMFC), fuel tanks, cryogenic for storage of hydrogen, storage batteries, drive trucks with traction electric motors.

For further calculations, the parameters of the main equipment operation and their technical characteristics were determined. The equipment was selected in the following order. First, the characteristics of traction electric motors were selected to provide the necessary tractive force. Then, taking into account the conversion of the electrical current in the inverter, the necessary voltage and current at the output of the battery pack was determined, the battery pack was formed and calculated, and the required PEMFC was subsequently determined which would provide the fastest and most economical charging of the battery pack. The main technical parameters for this equipment are presented in Table 1.

Table 1. The main technical characteristics of equipment for upgrading a suburban train.

\begin{tabular}{|c|c|}
\hline Name & value \\
\hline \multicolumn{2}{|l|}{ Traction asynchronous electric motor } \\
\hline power, $[\mathrm{kWt}]$ & 400 \\
\hline Maximum rotation frequency, $\left[\mathrm{min}^{-1}\right]$ & 4126 \\
\hline Starting torque, $[\mathrm{Nm}]$ & 3607 \\
\hline \multicolumn{2}{|l|}{$\begin{array}{l}\text { Accumulator batteries of the company } \\
\text { "Panasonic" NCR18650PF }\end{array}$} \\
\hline Nominal capacity, $[\mathrm{mAh}]$ & 2700 \\
\hline Rated voltage, $[\mathrm{W}]$ & 3,7 \\
\hline Maximum discharge current, [A] & 10 \\
\hline Maximum charging current, $[\mathrm{A}]$ & 5,4 \\
\hline Weight, $[\mathrm{kg}]$ & 0,047 \\
\hline amount NCR18650PF, [pieces]. & 12096 \\
\hline Cost, [USD] & $\$ 36288$ \\
\hline Weight (without case), $[\mathrm{kg}]$ & 568512 \\
\hline \multicolumn{2}{|l|}{ PEMFC } \\
\hline Power rating, $[\mathrm{kW}]$ & 240 \\
\hline Amperage, $\left[\mathrm{A}_{\mathrm{dc}}\right]$ & $0-1000$ \\
\hline Voltage, $\left[\mathrm{W}_{\mathrm{dc}}\right]$ & $240-480$ \\
\hline Maximum efficiency, [\% ] & 60 \\
\hline
\end{tabular}

The battery pack consists of "Panasonic" NCR18650PF batteries.

The connection of the batteries to the units occurs in stages in the same blocks, which are then connected together. This, first, is necessary because all connected batteries and units must have the same parameters, otherwise the parameter with the smallest value will be used in the connection.

Block A consists of 3 sub-blocks connected in parallel, the subblock consists of 4 batteries connected in series.

Block B consists of 3 sub-blocks connected in parallel, the subblock consists of 4 blocks A, connected in series.

Block C consists of 5 sub-blocks connected in parallel, the subblock consists of 4 blocks B, connected in series.

Block D consists of 2 sub-blocks connected in parallel, the subblock consists of 2 blocks $\mathrm{C}$, connected in series.

The energy transfer scheme for a modern commuter train is as follows: POMTE $\rightarrow$ DC / DC converter $\rightarrow$ Rechargeable battery $(120 \mathrm{~kW}) \rightarrow$ DC / AC step-up inverter $\rightarrow$ Traction electric motor $\rightarrow$ Gear drive from the traction motor to the wheel pair.

Previously, the efficiency of this transmission was determined by the formula, $\%$,

$$
\eta_{d t}=\eta_{p e m f c} \cdot \eta_{k d c / d c} \cdot \eta_{b a t} \cdot \eta_{i n v} \cdot \eta_{m o t} \cdot \eta_{t r},
$$

where $\eta_{\text {pemfc }}-$ efficiency of PEMFC, $\%$, in nominal mode, we accept $\eta_{\text {pemfc }}=60 \%$;

$\eta_{\mathrm{kdc} / \mathrm{dc}}-\mathrm{KDC} / \mathrm{DC}$ converter efficiency, $\%$,

$\eta_{\mathrm{kdc} / \mathrm{dc}}=97.5 \%$;

$\eta_{\text {bat }}$ - battery efficiency, $\%, \eta_{\text {bat }}=98,01 \%$;

$\eta_{\text {inv }}-$ efficiency of boosting inverter, $\%, \eta_{\text {inv }}=97,5 \%$;

$\eta_{\text {mot }}-$ efficiency of traction motor, $\eta_{\text {mot }}=95 \%$;

$\eta_{\text {tr }}$ - efficiency of gear transmission from the traction motor to the wheel pair, $\%, \eta_{\mathrm{tr}}=97 \%$.

As a result of calculations, the overall efficiency of the power transmission scheme for the upgraded train was obtained, which is equal to $51.51 \%$.

The next stage of the calculations was the determination of the parameters of the operation of the individual elements of the circuit under various modes of movement of a suburban train.

For the rolling stock in question, we determine the following modes of operation:

- traction mode (PT);

- idling speed (XX);

- Regenerative braking mode (TP);

- mechanical braking mode with the use of brake pads (TK).

In the following calculations we assume:

- when driving in traction mode when charging accumulator batteries more than $20 \%$, the electric power from the storage batteries (SB) is transferred to the boosting inverter (BI), and from it to the TEM.

- when driving in the traction mode with a SB charge equal to $20 \%$ or less, and provided that the SB charge is not enough to continue driving to the nearest stop, 
PEMFC is activated, which provides enough energy for the train to travel and power the auxiliary equipment.

- when driving idling, if the SB charge is less than $20 \%$ at the end of the rolling stock movement, the PEMFC turns on and continues to operate until the battery charge reaches the level at which the battery charge at the end of the train is at least $20 \%$. This condition may not be met only if after idle operation the regenerative braking mode is followed by further full stop, but in this case the battery charge can't be less than $5 \%$ at the end of the rolling stock in idle.

- braking mode with brake pads (BP) is intended only for complete stopping of rolling stock in 2 cases. 1 with standard braking, the brake pads are pressed against the rim of the gearbox to stop the SS at a speed of $5 \mathrm{~km} /$ h; 2 - with emergency braking, brake pads are activated simultaneously with regenerative braking to ensure maximum braking force (controlled by a computer, PEMFC does not work).

- In the PT mode, the energy comes from the TEM through the inverter on the battery. PEMFC does not work.

- to increase the overall efficiency, the battery pack is fully charged from the network at the service points, before the rolling stock is sent to the flight.

When constructing the traction characteristics of a suburban train in accordance with [9-12], the following basic equations were used.

The torque on the wheel pair is determined by the formula, $\mathrm{Nm}$,

$$
M_{k}=M_{T M} \times \mu \times \eta_{\text {gear }}
$$

where: $\mathrm{M}_{\mathrm{TM}}$ - torque on the shaft of the traction motor, $\mathrm{Nm}$;

$\mu$ - gear ratio;

$\eta_{\text {gear }}$ - gear efficiency.

The driving force, which is accounted for by one traction motor, is determined by the formula, $\mathrm{kN}$,

$$
F_{k d}=\frac{2 \times M_{k}}{D_{w}}
$$

where $D_{w}-$ wheel diameter on $\operatorname{rim}(0,95 \mathrm{M})$.

The tangential force of the traction of the entire rolling stock is determined by the formula, $\mathrm{kN}$,

$$
F_{k}=m \times F_{k d}
$$

where $\mathrm{m}$ - number of traction electric motors in a suburban train.

The force of traction on the adhesion of wheels with rails is calculated by the formula, $\mathrm{kN}$,

$$
F_{c u}=\psi_{\kappa} \times P_{c u}
$$

where $\mathrm{P}_{\text {сц }}$ - coupling weight of rolling stock, $\mathrm{kN}$;

$\psi_{\mathrm{K}}$ - coefficient of adhesion.

The results of calculations and construction of traction characteristics of the modernized suburban train are presented in Table 2 and in Fig. 2.
Table 2. Traction characteristics of a suburban train with an energy power plant on hydrogen fuel.

\begin{tabular}{|c|c|c|c|c|c|}
\hline $\mathrm{V},[\mathrm{km} / \mathrm{h}]$ & 5 & 10 & 20 & 30 & 40 \\
\hline $\mathrm{F}_{\mathrm{k} .}[\mathrm{N}]$ & 82688 & 82688 & 82688 & 82688 & 82688 \\
\hline & & & & & \\
\hline $\mathrm{V},[\mathrm{km} / \mathrm{h}]$ & 50 & 60 & 70 & 80 & 90 \\
\hline $\mathrm{F}_{\mathrm{k} .}[\mathrm{N}]$ & 82688 & 82688 & 75000 & 65000 & 60000 \\
\hline & & & & & \\
\hline $\mathrm{V},[\mathrm{km} / \mathrm{h}]$ & 100 & 110 & 120 & 130 & 140 \\
\hline $\mathrm{F}_{\mathrm{k}},[\mathrm{N}]$ & 53000 & 47500 & 43500 & 40000 & 36500 \\
\hline & & & & & \\
\hline $\mathrm{V},[\mathrm{km} / \mathrm{h}]$ & 150 & 160 & & & \\
\hline $\mathrm{F}_{\mathrm{k} .}[\mathrm{N}]$ & 35000 & 34500 & & & \\
\hline
\end{tabular}

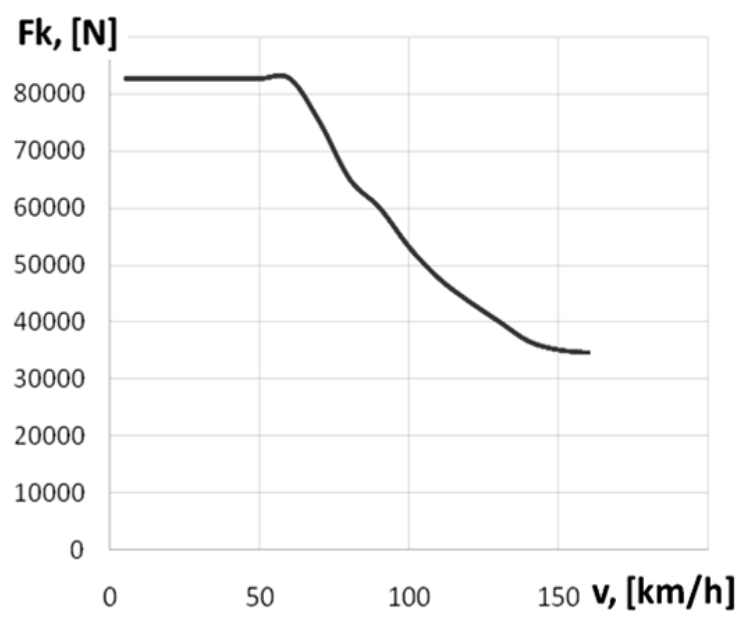

Fig. 2. Traction characteristics of a suburban train with an energy power plant on hydrogen fuel.

To verify the results obtained, traction calculations fulfilled The length of the route was chosen, the data for the site are shown in Table 3.

Table 3. Parameters of the study path.

\begin{tabular}{|c|c|c|c|c|c|c|}
\hline $\begin{array}{c}\text { Item } \\
\text { number }\end{array}$ & $\mathrm{Si},[\mathrm{m}]$ & $\begin{array}{c}\mathrm{i}, \\
{\left[\%{ }_{\mathrm{oo}}\right]}\end{array}$ & $\begin{array}{c}\mathrm{Ri}, \\
{[\mathrm{m}]}\end{array}$ & $\begin{array}{c}\text { Skri, } \\
{[\mathrm{m}]}\end{array}$ & $\begin{array}{c}\text { alfa, } \\
\text { deg }\end{array}$ & $\begin{array}{c}\mathrm{i} \text { used, } \\
{[\%}\end{array}$ \\
\hline 1 & 2 & 3 & 4 & 5 & 6 & 7 \\
\hline 1 & 1400 & 0 & & & & 0 \\
\hline 2 & 1100 & 1,9 & 800 & 350 & & 2,18 \\
\hline 3 & 1800 & 2,3 & 900 & 550 & & 2,54 \\
\hline 4 & 1300 & 2 & 750 & 400 & & 2,29 \\
\hline 5 & 800 & 0 & 600 & 300 & & 0,44 \\
\hline 6 & 700 & $-3,1$ & & & & $-3,1$ \\
\hline 7 & 1100 & $-3,4$ & & & & $-3,4$ \\
\hline 8 & 700 & 0 & & & & 0 \\
\hline 9 & 1300 & 11 & & & & 11 \\
\hline 10 & 1400 & 5 & & 650 & 20 & 5,38 \\
\hline 11 & 1400 & 4,7 & & 700 & 18 & 5.01 \\
\hline 12 & 1300 & 1,6 & & & & 1,6 \\
\hline 13 & 900 & 3,8 & & 700 & 15 & 4,06 \\
\hline
\end{tabular}


Continuation of table 3.

\begin{tabular}{|c|c|c|c|c|c|c|}
\hline 1 & 2 & 3 & 4 & 5 & 6 & 7 \\
\hline 14 & 800 & 2,8 & 900 & 300 & & 3,09 \\
\hline 15 & 400 & 3,9 & 800 & 150 & & 4,23 \\
\hline 16 & 500 & 0 & & & & 0 \\
\hline 17 & 1200 & $-8,1$ & & 600 & 25 & $-7,59$ \\
\hline 18 & 2300 & $-8,4$ & & 800 & 30 & $-7,94$ \\
\hline 19 & 2100 & -8 & & 650 & 24 & $-7,55$ \\
\hline 20 & 500 & 0 & & & & 0 \\
\hline 21 & 1600 & -4.4 & 850 & 400 & & $-4,19$ \\
\hline 22 & 1500 & -4 & 900 & 500 & & $-3,74$ \\
\hline 23 & 1200 & -1 & & & & -1 \\
\hline 24 & 1500 & 8 & & 600 & 25 & 8,51 \\
\hline 25 & 3300 & 8,5 & & 650 & 22 & 8,91 \\
\hline 26 & 1400 & 8,2 & & 700 & 16 & 8,48 \\
\hline 27 & 300 & 0 & & & & 0 \\
\hline 28 & 350 & $-3,4$ & 800 & 150 & & $-3,03$ \\
\hline 29 & 250 & -3 & 900 & 150 & & $-2,53$ \\
\hline 30 & 1900 & $-10,3$ & & & & $-10,3$ \\
\hline 31 & 500 & 0,6 & & & & 0,6 \\
\hline 32 & 1200 & 2,2 & & & & 2,2 \\
\hline 33 & 3500 & $-2,4$ & & & & $-2,4$ \\
\hline & & & & & & \\
\hline
\end{tabular}

The calculation of the retarding forces carried out according to known formulas [19].

The results of the calculations are presented in table 4 .

Table 4. Calculation of the retarding forces acting on the train

\begin{tabular}{|c|c|c|c|c|c|}
\hline $\mathrm{V},[\mathrm{km} / \mathrm{h}]$ & 5 & 10 & 20 & 30 & 40 \\
\hline $\mathrm{F}_{\mathrm{k}},[\mathrm{N}]$ & 82688 & 82688 & 82688 & 82688 & 82688 \\
\hline $\mathrm{w}^{\prime}{ }_{\mathrm{o}},[\mathrm{N} / \mathrm{kN}]$ & 1,957 & 2,030 & 2,220 & 2,470 & 2,780 \\
\hline $\mathrm{w}^{\prime}{ }_{\mathrm{o}}[\mathrm{N} / \mathrm{kN}]$ & 0,141 & 0,168 & 0,237 & 0,326 & 0,434 \\
\hline $\mathrm{W}_{\mathrm{o}}{ }_{\mathrm{o}},[\mathrm{kN}]$ & 4087 & 4238 & 4635 & 5157 & 5804 \\
\hline $\mathrm{W}^{\prime}{ }_{\mathrm{o}},[\mathrm{kN}]$ & 327 & 390 & 550 & 756 & 1009 \\
\hline $\mathrm{W}_{\mathrm{o}},[\mathrm{N}]$ & 4413 & 4628 & 5185 & 5913 & 6813 \\
\hline $\mathrm{F}_{\mathrm{k}}-\mathrm{W}_{\mathrm{o}},[\mathrm{N}]$ & 78275 & 78060 & 77503 & 76775 & 75875 \\
\hline $\mathrm{f}_{\mathrm{k}}-\mathrm{w}_{\mathrm{o}},[\mathrm{N} / \mathrm{kN}]$ & 37,49 & 37,39 & 37,12 & 36,77 & 36,34 \\
\hline $\mathrm{w}_{\mathrm{x}},[\mathrm{N} / \mathrm{kN}]$ & 2,454 & 2,525 & 2,720 & 2,985 & 3,320 \\
\hline $\mathrm{W}_{\mathrm{x}},[\mathrm{kN}]$ & 5123 & 5272 & 5679 & 6232 & 6931 \\
\hline $\mathrm{W}_{\mathrm{x}}+\mathrm{W}_{\mathrm{o}},[\mathrm{N}]$ & 5450 & 5661 & 6229 & 6988 & 7940 \\
\hline $\mathrm{w}_{\mathrm{ox}},[\mathrm{N} / \mathrm{kN}]$ & 2,297 & 2,338 & 2,456 & 2,623 & 2,837 \\
\hline $\mathrm{f}_{\mathrm{i}} \mathrm{k}_{\mathrm{p}},[\mathrm{N} / \mathrm{kN}]$ & 0,227 & 0,198 & 0,162 & 0,140 & 0,126 \\
\hline $\mathrm{B}_{\mathrm{t}},[\mathrm{N}]$ & 112,9 & 98,6 & 80,6 & 69,9 & 62,7 \\
\hline $\mathrm{p}_{\mathrm{t}}+\mathrm{w}_{\mathrm{ox}},[\mathrm{N} / \mathrm{kN}]$ & 2,351 & 2,385 & 2,494 & 2,656 & 2,867 \\
\hline $\begin{array}{c}0.5 \mathrm{~b}_{\mathrm{t}}+\mathrm{w}_{\mathrm{ox}} \\
{[\mathrm{N} / \mathrm{kN}]}\end{array}$ & 2,299 & 2,340 & 2,457 & 2,624 & 2,838 \\
\hline
\end{tabular}

Continuation of table 4

\begin{tabular}{|c|c|c|c|c|c|c|}
\hline $\mathrm{V},[\mathrm{km} / \mathrm{h}]$ & 50 & 60 & 70 & 80 & 90 & 100 \\
\hline 1 & 2 & 3 & 4 & 5 & 6 & 7 \\
\hline $\mathrm{F}_{\mathrm{k}},[\mathrm{N}]$ & 82688 & 82688 & 75000 & 65000 & 60000 & 53000 \\
\hline $\mathrm{w}_{\mathrm{o}}{ }_{\mathrm{o}},[\mathrm{N} / \mathrm{kN}]$ & 3,150 & 3,580 & 4,070 & 4,620 & 5,230 & 5,900 \\
\hline $\mathrm{w}^{{ }^{\prime}}{ }_{\mathrm{o}}[\mathrm{N} / \mathrm{kN}]$ & 0,562 & 0,710 & 0,878 & 1,066 & 1,273 & 1,500 \\
\hline $\mathrm{W}_{\mathrm{o}}{ }_{\mathrm{o}},[\mathrm{N}]$ & 6576 & 7474 & 8497 & 9645 & 10919 & 12318 \\
\hline $\mathrm{W}^{\prime}{ }_{\mathrm{o}},[\mathrm{N}]$ & 1307 & 1651 & 2040 & 2476 & 2957 & 3484 \\
\hline $\mathrm{W}_{\mathrm{o}},[\mathrm{N}]$ & 7883 & 9125 & 10537 & 12121 & 13876 & 15802 \\
\hline $\mathrm{F}_{\mathrm{k}}-\mathrm{W}_{\mathrm{o}},[\mathrm{N}]$ & 74805 & 73563 & 64463 & 52879 & 46124 & 37198 \\
\hline $\begin{array}{c}\mathrm{f}_{\mathrm{k}}-\mathrm{w}_{\mathrm{o}} \\
{[\mathrm{N} / \mathrm{kN}]}\end{array}$ & 35,830 & 35,240 & 30,880 & 25,330 & 22,090 & 17,820 \\
\hline $\mathrm{w}_{\mathrm{x}},[\mathrm{N} / \mathrm{kN}]$ & 3,725 & 4,200 & 4,745 & 5,360 & 6,045 & 6,800 \\
\hline $\mathrm{W}_{\mathrm{x}},[\mathrm{N}]$ & 7777 & 8769 & 9906 & 11190 & 12621 & 14197 \\
\hline $\mathrm{W}_{\mathrm{x}}+\mathrm{W}_{\mathrm{o}},[\mathrm{N}]$ & 9084 & 10419 & 11947 & 13666 & 15578 & 17681 \\
\hline \begin{tabular}{c}
$\mathrm{w}_{\mathrm{ox}},[\mathrm{N} / \mathrm{kN}]$ \\
\hline $\mathrm{f}_{\mathrm{i}} \mathrm{k}_{\mathrm{p}},[\mathrm{N} / \mathrm{kN}]$
\end{tabular} & 3,099 & 3,409 & 3,768 & 4,174 & 4,629 & 5,131 \\
\hline $\mathrm{B}_{\mathrm{t}},[\mathrm{kN}]$ & 57,642 & 53,799 & 50,810 & 48,419 & 46,463 & 44,833 \\
\hline $\begin{array}{c}\mathrm{b}_{\mathrm{t}}+\mathrm{w}_{\mathrm{ox}}, \\
{[\mathrm{N} / \mathrm{kN}]}\end{array}$ & 2,867 & 3,126 & 3,434 & 3,792 & 4,197 & 4,651 \\
\hline $\begin{array}{c}0.5 \mathrm{~b}_{\mathrm{t}}+\mathrm{w}_{\mathrm{ox}}, \\
{[\mathrm{N} / \mathrm{kN}]}\end{array}$ & 2,838 & 3,100 & 3,410 & 3,769 & 4,175 & 4,630 \\
\hline & & 0,102 & 0,097 & 0,093 & 0,090 \\
\hline
\end{tabular}

Continuation of table 4 .

\begin{tabular}{|c|c|c|c|c|c|c|}
\hline $\mathrm{V},[\mathrm{km} / \mathrm{h}]$ & 110 & 120 & 130 & 140 & 150 & 160 \\
\hline $\mathrm{F}_{\mathrm{k}},[\mathrm{N}]$ & 47500 & 43500 & 40000 & 36500 & 35000 & 34500 \\
\hline $\mathrm{w}_{\mathrm{o}}^{\prime},[\mathrm{N} / \mathrm{kN}]$ & 6,630 & 7,420 & 8,270 & 9,180 & 10,150 & 11,180 \\
\hline$w^{\prime \prime}{ }_{0}[\mathrm{~N} / \mathrm{kN}]$ & 1,747 & 2,013 & 2,299 & 2,605 & 2,931 & 3,276 \\
\hline $\mathrm{W}_{\mathrm{o}},{ }^{\prime},[\mathrm{N}]$ & 13842 & 15491 & 17266 & 19166 & 21191 & 23341 \\
\hline $\mathrm{W}^{\prime \prime}{ }_{0},[\mathrm{~N}]$ & 4058 & 4677 & 5341 & 6052 & 6808 & 7611 \\
\hline $\mathrm{W}_{\mathrm{o}},[\mathrm{N}]$ & 17899 & 20168 & 22607 & 25218 & 27999 & 30952 \\
\hline $\mathrm{F}_{\mathrm{k}}-\mathrm{W}_{\mathrm{o}},[\mathrm{N}]$ & 29601 & 23332 & 17393 & 11282 & 7001 & 3548 \\
\hline $\mathrm{f}_{\mathrm{k}}-\mathrm{w}_{\mathrm{o}}[\mathrm{N} / \mathrm{kN}]$ & 14,180 & 11,180 & 8,330 & 5,400 & 3,350 & 1,700 \\
\hline $\mathrm{w}_{\mathrm{x}},[\mathrm{N} / \mathrm{kN}]$ & 7,625 & 8,520 & 9,485 & 10,520 & 11,625 & 12,800 \\
\hline $\mathrm{W}_{\mathrm{x}},[\mathrm{N}]$ & 15919 & 17788 & 19802 & 21963 & 24270 & 26723 \\
\hline $\mathrm{W}_{\mathrm{x}}+\mathrm{W}_{\mathrm{o}},[\mathrm{N}]$ & 19977 & 22464 & 25144 & 28015 & 31079 & 34334 \\
\hline $\mathrm{w}_{\mathrm{ox}},[\mathrm{N} / \mathrm{kN}]$ & 5,681 & 6,280 & 6,927 & 7,621 & 8,364 & 9,155 \\
\hline $\mathrm{f}_{\mathrm{i}} \mathrm{k}_{\mathrm{p}},[\mathrm{N} / \mathrm{kN}]$ & 0,087 & 0,085 & 0,083 & 0,081 & 0,079 & 0,078 \\
\hline $\mathrm{B}_{\mathrm{t}},[\mathrm{N}]$ & 43,453 & 42,271 & 41,246 & 40,349 & 39,558 & 38,855 \\
\hline $\begin{array}{l}\mathrm{b}_{\mathrm{t}}+\mathrm{w}_{\mathrm{ox}} \\
{[\mathrm{N} / \mathrm{kN}]}\end{array}$ & 5,701 & 6,300 & 6,946 & 7,640 & 8,382 & 9,173 \\
\hline $\begin{array}{c}0.5 \mathrm{~b}_{\mathrm{t}}+\mathrm{w}_{\mathrm{ox}} \\
{[\mathrm{N} / \mathrm{kN}]}\end{array}$ & 5,682 & 6,281 & 6,927 & 7,621 & 8,364 & 9,156 \\
\hline
\end{tabular}


Calculation of the operating parameters of the equipment of the suburban train, consumption and return of energy when moving along a given section of the path are made on the basis of the parameters obtained in the graphical construction of motion curves. A fragment of the results and of the calculations presents in table 5 .

Table 5. Fragment of traction calculations of a suburban train on hydrogen fuel at the site.

\begin{tabular}{|c|c|c|c|c|c|}
\hline $\begin{array}{c}\text { Item } \\
\text { number }\end{array}$ & $\mathrm{S}$ & $\mathrm{V}$ & $\mathrm{t}$ & Added & Capacit \\
\hline 1 & 2 & 3 & 4 & 5 & 6 \\
\hline- & {$[\mathrm{m}]$} & {$[\mathrm{km} / \mathrm{h}]$} & {$[\mathrm{s}]$} & {$[\mathrm{kWt}]$} & {$[\%]$} \\
\hline $1-2$ & 27 & 5 & 19,44 & 0,162 & 98,28 \\
\hline $2-3$ & 86 & 15 & 20,64 & 0,172 & 96,41 \\
\hline $3-4$ & 135 & 25 & 19,44 & 0,162 & 95,64 \\
\hline $4-5$ & 164 & 35 & 16,87 & 0,140 & 94,76 \\
\hline $5-6$ & 196 & 35 & 20,16 & 0,168 & 94,62 \\
\hline $6-7$ & 65 & 31,69 & 7,38 & 0,061 & 94,26 \\
\hline $7-8$ & 224 & 38,38 & 21,01 & 0,175 & 93,01 \\
\hline $8-9$ & 287 & 48,38 & 21,36 & 0,178 & 91,43 \\
\hline $9-10$ & 351 & 58,38 & 21,64 & 0,180 & 89,47 \\
\hline $10-11$ & 236 & 61 & 13,93 & 0,116 & 88,18 \\
\hline $11-12$ & 573 & 73,62 & 28,02 & 0,233 & 85,55 \\
\hline $12-13$ & 741 & 83,81 & 31,83 & 0,265 & 82,48 \\
\hline $13-14$ & 486 & 90,99 & 19,23 & 0,160 & 80,57 \\
\hline $14-15$ & 1193 & 98 & 43,82 & 0,365 & 76,13 \\
\hline $15-16$ & 106 & 103,43 & 3,69 & 0,030 & 75,74 \\
\hline $16-17$ & 800 & 106,03 & 27,16 & 0,226 & 72,85 \\
\hline $17-18$ & 700 & 108,24 & 23,28 & 0,194 & 72,6 \\
\hline $18-19$ & 1100 & 107.35 & 36,89 & 0,307 & 72,30 \\
\hline $19-20$ & 700 & 108,94 & 23,13 & 0,192 & 69,75 \\
\hline $20-21$ & 1100 & 111,83 & 35,41 & 0,295 & 65,74 \\
\hline $21-22$ & 1400 & 109,075 & 46,21 & 0,385 & 65,29 \\
\hline $22-23$ & 229 & 104,95 & 7,86 & 0,065 & 65,22 \\
\hline $23-24$ & 344 & 100,29 & 12,35 & 0,102 & 66,97 \\
\hline $24-25$ & 339 & 91,21 & 13,38 & 0,111 & 68,67 \\
\hline $25-26$ & 276 & 81,21 & 12,23 & 0,102 & 70,03 \\
\hline $26-27$ & 211 & 71,21 & 10,67 & 0,088 & 71,14 \\
\hline $27-28$ & 222 & 60,60 & 13,19 & 0,109 & 72,21 \\
\hline 28-29 & 148 & 50 & 10,66 & 0,088 & 72,91 \\
\hline $29-30$ & 123 & 40 & 11,07 & 0,092 & 73,46 \\
\hline $30-31$ & 74 & 30 & 8,88 & 0,074 & 73,76 \\
\hline $31-32$ & 49 & 20 & 8,82 & 0,073 & 73,93 \\
\hline $75-76$ & 300 & 104,49 & 10,34 & 0,086 & 18,78 \\
\hline $76-77$ & 350 & 103,98 & 12,12 & 0,101 & 18,58 \\
\hline $77-78$ & 250 & 103,64 & 8,68 & 0,072 & 18,45 \\
\hline 78-79 & 1900 & 105,54 & 64,81 & 0,540 & 17,41 \\
\hline $79-80$ & 500 & 106,88 & 16,84 & 0,140 & 17,14 \\
\hline $80-81$ & 1200 & 104,45 & 41,36 & 0,344 & 16,47 \\
\hline $81-82$ & 1289 & 101,87 & 45,55 & 0,379 & 15,72 \\
\hline $82-83$ & 252 & 97,64 & 9,29 & 0,077 & 17,94 \\
\hline $83-84$ & 308 & 89,27 & 12,42 & 0,103 & 20,57 \\
\hline $84-85$ & 251 & 79,27 & 11,40 & 0,095 & 22,66 \\
\hline
\end{tabular}

Continuation of table 5

\begin{tabular}{|c|c|c|c|c|c|}
\hline 1 & 2 & 3 & 4 & 5 & 6 \\
\hline $85-86$ & 94 & 72,13 & 4,69 & 0,039 & 23,46 \\
\hline $86-87$ & 164 & 65 & 9,08 & 0,075 & 24,79 \\
\hline $87-88$ & 134 & 55 & 8,77 & 0,073 & 25,83 \\
\hline $88-89$ & 110 & 45 & 8,80 & 0,073 & 26,63 \\
\hline $89-90$ & 85 & 35 & 8,74 & 0,072 & 27,24 \\
\hline $90-91$ & 61 & 25 & 8,78 & 0,073 & 27,62 \\
\hline $91-92$ & 37 & 15 & 8,88 & 0,074 & 27,81 \\
\hline $92-93$ & 6 & 7,5 & 2,88 & 0,024 & 27,85 \\
\hline $93-94$ & 9 & 2,5 & 12,96 & 0,108 & 27,66 \\
\hline & & 0 & 120 & 1 & 36,50 \\
\hline
\end{tabular}

The obtained traction characteristic and verification calculations show that the power of the power plant on hydrogen fuel will be sufficient for efficient operation of the suburban train.

\section{Conclusions}

1. In work the international experience is considered the use of hydrogen as a fuel on rolling stock. Based on the fuel and economic indicators for a suburban train, the use of PEMFC as a power plant was chosen.

2. Technical parameters of the main equipment for a suburban train with a hydrogen fuel power plant, a scheme for energy transfer and transmission efficiency in general have been determined.

3 . For the suburban rolling stock, the main modes of operation in operation have been identified and assumptions have been made in calculations taking into account the features of proton-exchange membrane fuel cells.

4. An algorithm is proposed for constructing the traction characteristics of a suburban train on hydrogen fuel and a dependence of the traction force on the speed for the modernized rolling stock is constructed.

5. In the perspective of further research, the results could be extended by emission analysis and emission reduction of toxic compounds, for example [CO2].

6. In subsequent work, it is necessary to develop systems using proton-exchange membrane fuel cells on the train DPKr2, conduct their tests and specify the payback period of the train. Particular attention should be paid to solving the issue of logistics of production and supply of hydrogen to the points of refueling in the conditions of Ukraine.

\section{References}

1. Presentation: Hydrogen Rail Test Projects in Germany, Dr.-Ing. Ulrich Bünger (2017) URL: https://hydrail.appstate.edu/sites/hydrail.appstate.edu/ files/12 bunger.pdf, 30p.; (data zvernennya: 16.11.2018).

2. Kryukovskiy Vagonostroitelnyiy Zavod [Elektronniy resurs]. -http://www.kvsz.com. - (16.11.2018). 
3. Za strategiyu rozvitku Ukrzallznitsi do 2021 roku vklyuchno planuemo 5,9 mlrd dol. SShA kapitalnih investitsiy, z yakih blizko 4 mlrd dol. SShA, - na onovlennya ruhomogo skladu [Electronic resourse]: http://www.uz.gov.ua/press_center/up_to_date_topic/ page-31/458113/. - (data zvernennya: 17.11.2018).

4. Article: Railpower GG20B [Electronic resource]: [2010]

URL: https://en.wikipedia.org/wiki/Railpower_GG20B\#Fue 1_Cell_Testbed (date of the application 20.11 .2018 ).

5. Hydrogenics corporate presentation \& Renewable Hydrogen Activities [Electronic resource]: [May 2016] URL: https://www.slideshare.net/DenisThomas1/201605hy drogenicscompany-presentationcompressed (date of the application 16.11.2018).

6. Article: How a Fuel Cell Works [Electronic resource]: [2016] URL: http://www.protonmotor.com/how-a-fuel-cell-works/ (date of the application 17.11.2018).

7. http://tainy.net/13400-vodorodnoe-toplivo.html (date of the application 17.11.2018).

8. https://www.popmech.ru/technologies/371842vodorodnyy-transport-tehnologiya-budushchego-ilipolnyy-proval/(date of the application 17.11.2018).

9. Vodorodne toplivo, ekonomika i ekologija http://www.newchemistry.ru/letter.php?n_id=1236 (date of the application 17.11.2018).

10. https://auto.today/bok/4339-kak-rabotaetvodorodnyy-dvigatel.html (date of the application 18.11.2018).

11. V Germanii prezentovali poezd na vodorodnom toplive https://www.segodnya.ua/world/europe/v- germanii-prezentovali-poezd-na-vodorodnomtoplive-1071211.html (date of the application 16/11/2018)

12. Coradia iLint: V Germanii nachal kursirovat pervij v mire vodorodnij poezd. [Electronic resource]: [2016] URL: http:// iq.intel.ru/coradia-ilint-\%D0\%B2$\% \mathrm{D} 0 \% \mathrm{~B} 3 \% \mathrm{D} 0 \% /$ (date of the application 25.07.2018).

13. Nemecki poezda poedut na vodorode. https://www.kommersant.ru/doc/3134887. (date of the application 16/11/2018).

14. Grigorovich D.N., Bulletin of the Joint Scientific Council, 6, 37-50 (2013).

15. A. Falendysh, P. Kharlamov, O. Kletska, N. Volodarets, Transportation Research Procedia, 14, 665-671 (2016).

16. Anatoliy Falendysh, Mykyta Volodarets, Olha Kletska, Viktoriia Hatchenko, The impact of the type of operation on the parameters of a shuning diesel locomotive with hybrid power plant, MATEC Web Conferences 133.03003 (2017).

17. Merkisz J, Bajerlein M, Daszkiewicz P 2012 The Influence of the Application of Photovoltaic Cells in City Buses to Reduce Fuel Consumption- $\left(\mathrm{CO}_{2}\right)$ and Exhaust Emissions (HC, PM, and $N O_{x}$ ) Lecture Notes in Information Technology vol. 13.

18. A. Falendysh, TEKA. Commission of motorization and energrtics in agriculture, 12, 58-63 (2012).

19. A. Falendysh, O. Chyhyryk, O. Kosariev, Kh: UkrDUZT, 175, 12-23 (2018).

20. Osipov S.I., Osnovy elektricheskoy $i$ teplovoznoy tyagi, M.: Transport, (1985). 